\title{
CRITICAL READING SKILL AND ITS IMPLICATION TO SPEAKING ABILITY IN MULTICULTURAL CLASSROOM
}

\author{
Diah Retno Widowati ${ }^{1}$ Kurniasih $^{2}$ \\ Faculty of Teacher Training and Education, Universitas Islam Malang - INDONESIA ${ }^{1,2}$ \\ e-mail: d.retnowidowati@unisma.ac.id
}

\begin{abstract}
People need good background knowledge before they speak. The purpose of the present study was to discuss the implication of students' critical reading skill to their English speaking performance in classroom activity. Researchers also would like to discuss the effect of multicultural atmosphere to students' speaking skill. This study employed descriptive qualitative design to explain students' speaking ability after they read. Therefore, students' speaking ability could be mapped out after being stimulated by critical reading. The major finding of this study were the fact that reading and analyzing the texts was important for students before they speak. Gaining previous information before students speak made them feel more comfortable and be able to deliver or speak up their ideas better. Besides, the multicultural background of the students were not significantly affect their speaking ability. Yet, some students felt difficult in pronouncing ' $\mathrm{f}$ ' in 'of', ' $\mathrm{v}$ ' in very', and ' $\mathrm{o}$ ' in open' correctly. This was because of their pronunciation habit in their homeland.
\end{abstract}

Keywords: critical reading, speaking ability, multicultural classroom

\section{Introduction}

Speaking activity needs wide background knowledge of the speaker. An individual needs to possess various language skill to be able to deliver ideas, hopes, feelings, and information (Pamela, 1991) actively. Active language skills are necessary for people to write and speak, while passive language skills are needed for ones to read and listen (Crow, 1986). In order to master active language skills, an individual needs to be able to know passive skills. In other words, someone must be able to read before speak.

The necessity of reading is getting higher. Based on the report of literature bureau in The United State, reading is a stepping stone to be success, not only in education but also in everyday life. According to Gallik (1999), without proper reading ability, the opportunity to present self-ability is almost zero. Therefore, people are urged to read as many and various works as possible to obtain extensive knowledge as the basic to speak. However, the idea of delivering information from speaking activity is difficult for many people. Studies by Alonzo (2014), Sarwar, et al. (2014), and Alharbi (2015) revealed that former students of senior high schools were rarely to be able to speak properly. Mwamba (2005) claimed that most senior high school students were reluctant to express the ideas well that make them prefer to stay quiet. The similar phenomenon also happen in Saudi Arabia, in which the speaking ability of many students was low due to the lack of authentic language learning practice (Alharbi, 2015). Meanwhile, in Indonesia, there are a lot of students feel anxious to speak in class. Some students are only able to raise question without providing solutions. It is because the lack of knowledge possessed by students due to the lack of obtaining information through reading. Students are urged to be critical in reading since this can help them to add background knowledge better. Critical reading is used not only to find the flaw of a discourse, but also to find evidence and data to support argument. 
This is beneficial to be practiced by university students. Basically, university students should be able to express their ideas in a spoken form. Ironically, many university students of English department feel difficult in expressing ideas and opinions related to topics given during lecturing activities. Not only that, the language used by students also improper in terms of pronunciation. In addition, the multicultural condition in classroom contribute to the understanding of the students, especially in understanding point of view.

Multiculture is a diversity condition that needs to be cope with every indivual in a multiculture country, where a lot languages, dialects, cultures, and histories gather into one. Moreover, it cannot be denied that universities have become one of places where people from various areas come. To cope with this situation, one language need to be used to understand what other people said. In this study, the multicultural condition comes from the different background dialects and perception of the university students. The students come from different areas or even islands in Indonesia, thus the classroom atmosphere is considered as a multicultural classroom.

According to Luchternburg (2003, as cited in Rasimin, 2017) multicultural education has 3 main poin, namely: (1) all students are the target population of education; (2) students' muticulture oriented; and (3) is integrated as main objective. Willing or not, the multicultural condition must be faced by students, while multicultural might affect the students' language skill. Liliweri (2005) claims that multicultural education is a learning strategy that is based on multicultural background of students to build a social behavior. This condition is an inevitable in several multicultural countries. Poudel (2010) investigated Nepali students who took English course. It was revealed that the Nepali students were lack of convenience in attaining proper education in Nepali, instead, most learning were conducted and aimed at English. It seems that the Nepali language interference the students' English skill. In this study, the speaking skill of the students was integrated to the students' multicultural background.

The purpose of the study was intended to know the students speaking ability after they experienced critical reading activity. In addition, the students' speaking ability also connected to the students' background culture to see if there is effect of the multiculturalism in the students' speaking skill.

\section{Method}

This study employed quantitative design with descriptive method. Quantitative study was a study that emphasize the need of data in the form of numbers (Arikunto, 2010). Even though the data were in the form of number, they are analysed descriptively. The quantitative data was used to analyze the relation between students' critical reading activity with their speaking ability. Meanwhile the involvement of multicultural condition in the speaking activities was aimed at explaining if the background cultures of the students affected the students' speaking ability.

The study involved 55 fourth semester students who took Speaking IV course academic year 2017/2018 in Universitas Islam Malang. The numeric data were taken from the students' score in speaking III class. The data were used to obtain information related to the importance of reading before speaking. Beside score, the researchers also obtain data from Multilingual English Classses Language Use questionnaire. This questionnaire was aimed at 
obtaining data related to students' daily use of language. Moreover, the data related to the students' speaking ability and the students' background culture were obtained through classroom observation. The researchers performed as the lecturer of speaking class.

\section{Findings And Discussions}

\section{The Effect of Critical Reading to Speaking Ability}

As the researchers taught speaking III classes, the students underwent reading activity preceding the speaking activity. They had to read the texts critically. The topics of the reading texts were similar to the topics of speaking activity. The scores of the students' speaking were represented by the exam speaking scores, as presented below.

Table 1. The Students' Speaking Scores

\begin{tabular}{|c|l|c|c|l|c|}
\hline No. & \multicolumn{1}{|c|}{ Students } & Score & No. & \multicolumn{1}{|c|}{ Students } & Score \\
\hline 1. & FAS & 83 & 29. & IUS & 78 \\
\hline 2. & MES & 77 & 30. & AISN & 82 \\
\hline 3. & SWA & 85 & 31. & NQ & 77 \\
\hline 4. & SA & 87 & 32. & AZZ & 84 \\
\hline 5. & RNF & 85 & 33. & ATD & 82 \\
\hline 6. & AJY & 82 & 34. & SKM & 81 \\
\hline 7. & KNJ & 78 & 35. & MAF & 65 \\
\hline 8. & PRA & 79 & 36. & MGR & 79 \\
\hline 9. & RAW & 81 & 37. & ABP & 82 \\
\hline 10. & FM & 82 & 38. & HSJ & 82 \\
\hline 11. & MN & 82 & 39. & KSR & 80 \\
\hline 12. & AAS & 83 & 40. & ARF & 86 \\
\hline 13. & EP & 85 & 41. & RR & 83 \\
\hline 14. & DMS & 85 & 42. & AH & 85 \\
\hline 15. & WE & 86 & 43. & WNL & 80 \\
\hline 16. & EAN & 85 & 44. & DTRB & 79 \\
\hline 17. & PSI & 83 & 45. & ENL & 80 \\
\hline 18. & AMI & 82 & 46. & RIS & 80 \\
\hline 19. & AW & 80 & 47. & THR & 82 \\
\hline 20. & VII & 79 & 48. & DSM & 82 \\
\hline 21. & NNI & 81 & 49. & SBU & 49 \\
\hline 22. & NRF & 79 & 50. & KU & 77 \\
\hline 23. & MFF & 79 & 51. & MAR & 78 \\
\hline 24. & MK & 80 & 52. & AAS & 73 \\
\hline 25. & FUA & 85 & 53. & THS & 77 \\
\hline 26. & RF & 82 & 54. & USH & 84 \\
\hline 27. & MH & 80 & 55. & MNA & 74 \\
\hline 28. & CY & 82 & & & \\
\hline & & & \\
\hline
\end{tabular}

From the table above, we can see that 51 students out of 55 students obtained score above 75 , means they were able to deliver their opinion well related to the topic given after they underwent critical reading activity. During the critical thinking activity, students were to (1) examine the evidence or arguments, (2) elicit the effecs oon the evidence, (3) elicit the 
limitation of the content of the manuscript, (4) interpret the content of the texts, and (5) decide your position towards the author's arguments, opinions, and conclusions ("What is Critical Reading?", 2009, pg. 1).

Based on the data obtained, reading activity critically before the students speak, is useful for those who want to express their ideas. Through reading activity, the students can gather much information, gather evidences or data related to the topic given by the teacher. Agustina (2008) states that reading critically aims at knowing evidences within texts before readers make assumptions to a particular situation. Reading activity before speaking contributes to the students' self-confidence since the students can based their ideas or opinions on empirical data or evidences. Through critical reading, readers are not merely spell words, they along with authors, indirectly, consider about the discussed matters.

This is in line with Patesan, Balagiu, Zechia, and Alibec's (2014) statement that students read a text related to a specific topic, they undergo the activity of broadening the comprehension and reasoning as well as developing to observe, compare, and contrast. Based on the mean score obtained by the students (80.3), it can be assumed that they were able to perform their opinion and ideas during speaking activity well after they read related texts critically. It means that the critical reading affect the students' speaking skill.

\section{The Language Used by the Students in Classroom}

The result of the Multilingual English Classes Language Use showed that $100 \%$ students speak either bahasa Indonesia or local language in their daily activity. This is not surprising since English is not the second language of Indonesian people. Besides, not even one of the students' family background speak in English. $67 \%$ of the students speak local languages to their parents and friends from the same hometown, while $33 \%$ of them speak in bahasa Indonesia.

Regarding the question "Does it help you learn English better if you use your mother tongue in English class?", 93\% students admitted that it is easier for them to understand the content of learning if they use bahasa Indonesia. Not only it is easier for the students to understand the learning, speaking bahasa Indonesia also make the feel comfortable to get along with their friends. It is in line with Zamroni (2011) that the involvement of multicultural condition in classroom activity is useful to (1) develop students' critical thinking ability towards background knowledge, (2) have self-awareness and be able to control his prejudice towards others, (3) understand that every knowledge can be used to improve social welfare, (4) be able to apply knowledge, and (5) understand the relationship between one phenomena and another one.

However, based on the result of the questionnaire delivered to speaking class students, it can be seen that 42 out of 55 students $(76 \%)$ agree that using bilingual is more effective for them to understand the lecturer's instruction. On the other hands, $98 \%$ students claimed that they learn English better through listening music, where they cannot find the Indonesian translation of the lyrics, while the rest students said that they like reading books to learn English. 


\section{The Relation between Cultures and the Students' Speaking Skill}

The multicultural condition of the students played a quite important role during the speaking classroom activity. Based on the questionnaire, from 55 students, 20 of them are from Java, 16 students are from Madura, 4 students are from Nusa Tenggara Barat, 8 students are from Borneo, 3 students are from Jakarta, 1 student is from Celebes, 1 students is from Nusa Tenggara Timur, and the rest 2 students are from South Sumatera. All of them come from various social economic and family education background. These differences affect the students' way of thought, dialect in speaking English during class activity, attitude, and also self-confidence.

According to Skeel (1995) multicultural education is a condition of considering human uniqueness without discriminating culture, skin colour, physical appearance, gender, dialect, and financial background. Based on the students' performances during the classroom activities, the researchers noted that the students who come from Nusa Tenggara Barat, Celebes, and Borneo were difficult to pronounce ' $\mathrm{f}$ ' and ' $\mathrm{v}$ '. Instead of 'of' they pronounced 'op', 'difficult' became 'dipphicult' (with aspirated /p/ sound, 'very' became 'phery'. Besides, it seemed difficult for some of them to differ 'o' sound in 'open' and 'on'. Yet, this pronunciation was not the major problem in and still could be understood and meaningful.

The students' speaking activity were emphasized more on the message sent during the speaking performances. It is because the lifelong process and the researchers wanted to help the students to develop their own self confidence in speaking, regardless the differences found. The researchers created a learning atmosphere where diversity among the students and the differences are not seen as an impediments to learning. The students were given the same opportunity to learn.

\section{Conclusion}

Reading is an inevitable activity to gain information. Through reading, students were able to deliver their opinion better and show better performance. It can be seen from the final examination score that most students achieved score $>75$. Meanwhile the bilingual used in classroom activity made the students easier to understand the learning instruction and learn better. Due to the technology today, many students learn English not only from books but also from music. In meant that even tough students feel comfortable when they use both English and Indonesia, students still have many alternatives to learn English.

Multicultural condition, in the forms of family education background, dialect, and hometown affect the students' performance in terms of the way they pronounce some words. Yet this is not the major problem in speaking since the points of their message were delivered well and acceptable. In brief, involving multicultural condition in learning is an inevitable in a multicultural country, like Indonesia. Yet, the situation should not be seen as a hindrance, instead as resources to be recognized, catered to, and appreciated.

\section{ACKNOWLEDGEMENT}

This article was written based on the study result of Institution Grant funded by LPPM Unisma (HI-ma). The researchers would like to thank to the Rector of Unisma who gave us an opportunity to conduct this study and sponsored this study through LPPM Universitas Islam Malang. The researchers also would like to thank to the students of Speaking III Class who had cooperated well during the study. 


\section{References}

Agustina. 2008. Pembelajaran Keterampilan Membaca. Padang: Jurusan bahasa dan Sastra Indonesia dan Daerah UNP.

Alharbi, A.H. 2015. Improving Students'English Speaking Proficiency in Saudi Public Schools. International Journal of Instruction. Vol. 8 (1)

Alonso, A.R. 2014. Teaching Speaking: An Exploratory Study in Two Academic Contexts. PORTA LINGUARUM. Vol 22

Arikunto, S. 2010. Prosedur Penelitian Suatu Pendekatan Praktik. Jakarta: Rineka Cipta.

Crow, J.T. 1986. Receptive Vocabulary Acquisition for Reading Comprehension. The Modern Language Journal. Vol. 70 (3): 242-250.

Gallik, J.D. 1999. Do They Read for Pleasure? Recreational Reading Habits of College Students. Journal of Adolescent and Literacy. Vol. 42 (6): 480-488 Liliweri, Alo. 2005. Prasangka \& Konflik:Komunikasi Lintas Budaya Masyarakat Multikultural. Yogyakarta. LKiS.

Mwamba, R. 2005. An Investigation into Factors that Hinder the Instruction of Oral Communication Skills in English Kenyan Secondary Schools: A Case of Kisii District. Eldoret Moi University

Pamela, J.S. 1991. Test of English as a Foreign Language $\left(6^{\text {th }} E d\right)$. New York: Barron's Educational Series Inc. Pariaman. Ahasa dan Sastra Indonesia. Vol 1 (2): 521-527 Liliweri, A. 2005. Prasangka \& Konflik: Komunikasi Lintas Budaya Masyarakat Multikultural. Yogyakarta: LKiS

Patesan, M, Balagiu, A, Zechia, D, Alibec, C. 2014. Critical Reading. Buletin Stuntific. Vol. $31(1): 62-67$

Poudel, P. P. 2010. Teaching English in Multilingual Classrooms of Higher Education: The Present Scenario. Journal of NELTA. Vol. 15 (1-2): 121-133

Ramadani, P.N., Basri, I., Emidar. 2013. Hubungan Kemampuan Membaca Kritis Dengan Kemampuan Menulis Argumentasi Siswa Kelas Viii Smp Negeri 7

Rasimin. 2017. Implementasi Model Pembelajaran Multikultural Untuk Meningkatkan Kompetensi Mahasiswa. Inferensi. Vol. 11(1): 141-162

Sarwar, M., Alam, M., Hussain, A., Shah, A.A,Jabeen, M. 2014. Assessing English Speaking Skills of Perspective Teachers at Entry and Graduation Level in Teacher Education Program. Language Testing in Asia: A Springer Open Journal.

Skeel, D.J. 1995. Elementary Social Studies: Challenge for Tomorrow's World. New York: Harcourt Brace College Publishers.

Student Learning Development. 2009. What is Critical Reading?. University of Leicester.

Zamroni. 2011. Pendidikan Demokrasi pada Masyarakat Multikultural. Yogyakarta: Gavin Kalam Utama. 